\title{
Achievements in automation of heat exchangers brazing
}

\author{
Osiągnięcia w automatyzacji procesów lutowania twardego \\ wymienników ciepła
}

\begin{abstract}
One of the most difficult problems is brazing of tube plate of large copper heat exchangers. Ordinarily the manual brazing with power flame torch is used. Problem solving included new filler metal form application simultaneously with full automation of fluxing, transporting, brazing metal filling and heating processes. Wide gap filling and equal heating were achieved by heat gradient creation during brazing. Automation of heat exchangers allowed increasing of efficiency up to 4 times.
\end{abstract}

Keywords: flame brazing; process automation; copper, copper alloys

\section{Streszczenie}

Jeden z najistotniejszych problemów spajania dotyczy lutowania twardego płyty sitowej $w$ dużych miedzianych wymiennikach ciepła. Zazwyczaj tego typu elementy łączy się metodą lutowania twardego płomieniowego przy zastosowaniu palnika gazowego. W celu rozwiązania różnorakich problemów wprowadzono nowy sposób aplikowania spoiwa, jednocześnie $z$ automatyzacją procesów dozowania topnika, transportu, wypełniania lutem i nagrzewania. Stworzenie nagrzewania gradientowego pozwoliło osiągnąć równomierne nagrzewanie i wypełnianie szerokich szczelin. Automatyzacja lutowania wymienników ciepła pozwoliła zwiększyć czterokrotnie wydajność procesu.

Słowa kluczowe: lutowanie twarde płomieniowe; automatyzacja procesu, miedź; stopy miedzi

\section{Introduction}

The large-dimensioned heat exchanger high-temperature brazing automation awakes a great interest within the modern engineering industry. In particular, concerning the diesel locomotive radiators. Large dimension of articles, big mass and thermal capacity and the large quantity of joint elements make the automation process to be a formidable task. The brazing processes automation presumes the heat exchanger producer's striving towards rising the componentry manufacture accuracy and the assemblage accuracy of an article, prior to brazing. In this work, the solution of a problem of the diesel locomotive copper radiator tube plate brazing by means of flame torch brazing by copper-phosphoric brazing metal is presented.

\section{Joint design Technological solutions search}

At present time at Russian factories, the diesel locomotive radiator tube plate is brazed manually by means of the powerful flame torch. Brazing metal is entered manually in the form of bars $10 \mathrm{~mm}$, or the ring-embedded elements are applied. Structure feature consists in that, that tubes are fabricated of the copper alloy tombac. The tube plate represents a copper box with punched or stamped holes of oval form. The amount of holes may reach up to 68 pieces (fig. 1).

The coupling form of tubes and holes has variable configuration at different manufacturers. Large quantity of joint elements results in irregular gaps, since the attempts to diminish a gap lead to the assemblage complication. The assembled radiator section length makes more than $1.2 \mathrm{~m}$. In our case, the joint represents coupling of the tube flat surface with the curved hole of the tube plate (fig. 2), characterized by a variable gap.

The most problems appear with the heating-up efficiency, as far as the brazing of already assembled heat exchanger is carried out, when thin copper fins are placed on the tube. It increases the heat transfer into article volume and results in time increase, while heating-up to the brazing temperature. Application of torches with local heat requires high skill from operator, which consists, on the one hand, in the ability to heat up brazing zone intensively, and on the oth-

Prof. Igor Pashkov - PBSU, Moscow, Russia.

Autor korespondencyjny/Corresponding author. paikaspp@gmail.com 




Fig. 1. Locomotive radiator section for brazing

Rys. 1. Obszar chłodnicy lokomotywy przeznaczony do lutowania twardego

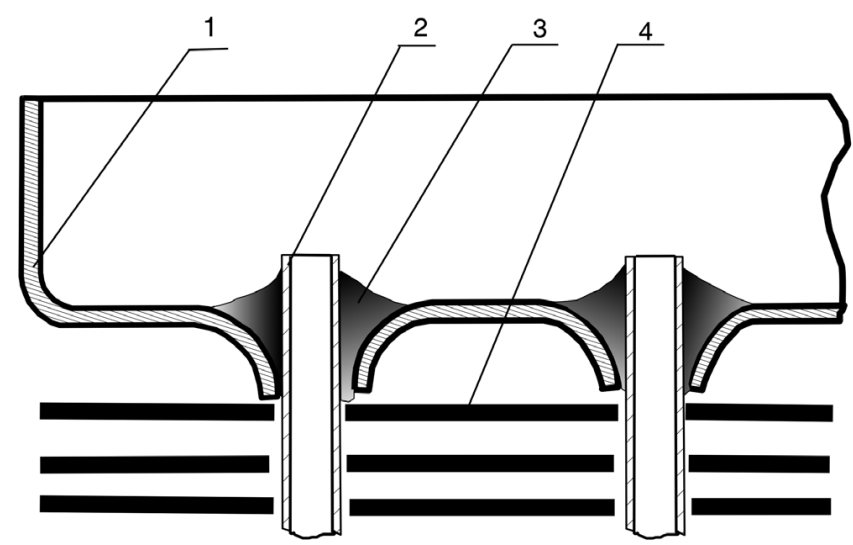

Fig. 2. Scheme of joints: 1-tube plate; 2-oval tombac tubes; 3-brazing metal; 4-copper fins

Rys. 2. Schemat złączy lutowanych: 1 - płyta sitowa, 2 - owalna rura ze stopu tombak, 3 - spoiwo z lutu twardego, 4 - żebra miedziane

er hand, not to burn through the protruding ends of tubes, which thickness may be $0.3-0.4 \mathrm{~mm}$. At that, brazing metal is always entered from the heated side. Its placement on not enough heated surface leads to balls formation, oxidizing and burning-out of phosphorus. For good wetting of copperzinc alloy tubes, the brazing process provides for the borate flux usage.

Thus, for the solution search of tube plate brazing process automation, it is necessary to solve the following problems simultaneously:

- Effective and uniform heating;

- Flux applying on joint surfaces;

- Brazing metal dosing and its feeding towards the brazed joint formation zone;

- Tubes and exchanger elements burning-out prevention.

As it has been described in article [1] already, one of the successful solutions for tube plates brazing may be the usage of brazing powders, which are applied on a tube plate surface uniformly before brazing. At that, the powder should not be too fine, in order not to be flown away by the burner flame stream, and should not be too coarse, since the uniformity of its laying and dosing becomes more complicated.
The best solution of choosing of brazing alloy was achieved with Cu-6P-4Sn composition [2,3], which had rather wide melting interval $\left(680-810^{\circ} \mathrm{C}\right)$. It provided good gap filling and avoided metal leaking in the bottom part of tube plate through wide gaps.

Considering the heating-up intensity and productivity of process, the heating by means of linear natural gas - oxygen torch has been chosen. The flame width should overlap all protruding tubes completely. Under such a method, the tube plate heating occurs more uniformly. Varying speed and distance between the torch and the tube plate, it is possible to achieve practically the uniform heating of the whole surface. The problem was only in retention of brazing powder under the flame jet. Flux and its laying method should play the key role in this problem solution.

\section{Fluxing prior to brazing Brazing powder dosing}

Taking into consideration, that the gap between the tube surface and the copper plate may reach $0.5-1 \mathrm{~mm}$ locally (especially while using the hole punching technology), it is necessary to exclude the pouring of brazing powder with average size particles of 150 microns through the noted gap. If preliminary all surface with tubes is moistened by flux solution with foaming agent, then the forming foam will prevent the powder pouring, the high wettability of powder particles solution forms the cohesion between the particles quickly, that accelerates sintering and formation of a continuous coverage of brazing powder on the tube plate surface.

Therefore, the problem solving was found via the application of borate flux aqueous solution with surface-active substance additives for foaming. Flux solution was sprayed by means of 4 spraying nozzles to coat all junction places within 150x200 $\mathrm{mm}$ square.

\section{Peculiarities of heating with linear flame torch}

As it was noted above already, linear natural gas-oxygen torch had been used for heating the tube plate with tube leads. For the correct thermal condition, it is important to choose the torch distance and the algorithm of its movement along the tube plate. The matter is, that while flame torch moving, it is necessary to reach such a regime, that the powder should melt, and the brazing metal spreading upon tubes should occur directly under the torch flame. It is also necessary to consider, that brazing alloy overheating leads to its permeation into gaps between the tube and the plate, and its amount diminishes on the tube plate. It may result in brazing metal shortage and the article overheating. For the passage of brazing alloy through gaps prevention, the air blow-through of heat exchanger has been proposed with the flow velocity control in the direction opposite to the flame torch moving (fig. 3).

Thus, forming the considerable temperature gradient along the tube plate section, it is possible to achieve good brazing of the tube with plate junction and to minimize the brazing metal pass through gaps. At that, it is necessary to keep in mind, that as soon as brazing melt fills gaps between the tube and the plate, the heat dissipation while purging increases immediately, protecting the article from overheating and tubes burn-out. It is necessary only to coordinate the air flow velocities while purging with the speed of torch moving, that along the torch line the brazing melt 


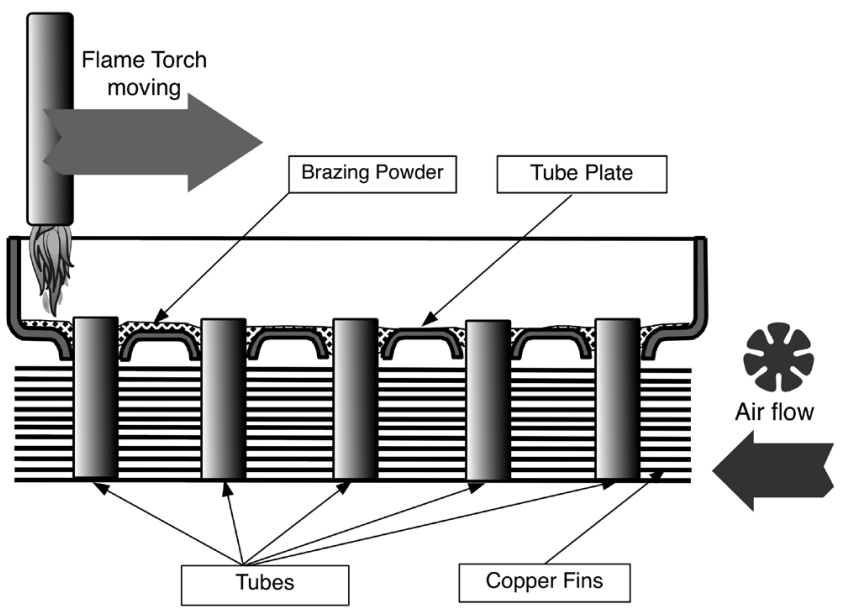

Fig. 3. Scheme of tube plate brazing with flame torch moving and air purging

Rys. 3. Schemat lutowania twardego płyty sitowia z kierunkiem przemieszczania palnika gazowego i powietrza

temperature was uniform along the whole article width. The purging system of heat exchanger may be used also for its subsequent cooling after brazing for the copper fins surface oxidability decrease.

\section{Brazing process automation Basic results}

The brazing post consists of two independent step-motion conveying systems, used for cartridges moving, in which the heat exchangers are placed. Cartridges serve for the fixing accuracy provision of the tube plate under the actuating mechanism for flux applying, powder dosing and brazing. On the first conveyor, there are loading post, fluxing post, brazing powder dosing post. On the second conveyor, there are the brazing post and the article subsequent cooling post. Moving of cartridges between conveyors is implemented by means of pneumatic sliders (fig. 4). Simultaneously, the loading post is the brazed section unloading place, as well.



Fig. 4. Scheme of equipment for radiator sections brazing

Rys. 4. Schemat wyposażenia do lutowania twardego elementów chłodnicy

Automatic plant operation is carried out as follows. Operator installs the article in the cartridge and pushes "START" button. Conveyor moves the article to the fluxing position. After installation of the second article and "START" button pressing, the first article moves to the brazing powder dos- ing post, at this time the second article is fixed at the fluxing post. After the third article installation, the first one is displaced by slider on the second conveyor, at the brazing post and after fixation, the heating starts. At this time, using the conveyor independence, operator fixes the next article. The second article is also displaced on the second conveyor before the brazing post. Thus, the limiting time is the brazing time, which makes 2-2.5 minutes, that is several times less, than the brazing time while manual heating.

\section{Joints quality and structure}

Adjusting speed of torch moving, a distance between tube plate and torch, using of foaming borate flux good spreading and joint creation has been achieved. Because of uniform distribution of powder brazing alloy and its equal melting along torch flame good filets forming without porosity and voids has been reached (fig. 5a). Microstructure research (fig. $5 b$ ) revealed dense joint structure without any appreciable thin tube surface dissolution by the melt. It was due to cooling with air blowing below the tube plate when the brazing process was carried out.


Fig. 5. Brazed joint of good quality: a) an uniform distribution of powder brazing alloy, resulted in joint without porosity and voids, b) microstructure of joint without surface dissolution by the melt Rys. 5. Połączenie lutowane o dobrej jakości: a) równomierne rozmieszczenie lutu, umożliwiające uzyskanie złącza bez porowatości i pustek, b) mikrostruktura połączenia bez niezgodności i nadtopień 


\section{Conclusion}

1. Automation of large-size heat exchangers (diesel locomotive heat exchangers) brazing is possible, while using the brazing powder and the linear flame torch heating.

2. For the exclusion of brazing melt leakage after its melting and saving it in gaps, and also the reduction of thermal exposure on radiator and tubes, it is necessary to implement the blow of heat exchanger in the direction, opposite to the torch movement.

3. Borate flux solution with the foaming agent application has allowed retaining brazing metal in the powder form on the article surface, while the torch approach and its moving along the article.

4. Automation of brazing the tube plate with radiator tubes has allowed increasing the process productivity several times.

\section{Acknowledgment}

The author gratefully acknowledges the design and technical support of I. Baranov from "Technologies of Engineering".

\section{Literature}

[1] I.N. Pashkov, A.I. Pashkov, I.A. Ahmetzianova: Using of Cu-P based powders for large area brazing joints. Brazing, High Temperature Brazing and Diffusion Welding, 9-th Int.Conf., Aachen, 19-21 June 2010.

[2] I. Pashkov, A. Shapiro, I. Ilina: Properties and applications of Cu-based silver free brazing filler metals made by rapid solidification technique. Proceeding of the 3rd International Brazing and Soldering Conference, San-Antonio, Apr. 24-26, 2006, p. 157-166.

[3] I. Pashkov, S. Shokin: The experience in development, producing and using of copper-based brazing alloys. 1 Int. Conf. Postep w technologiach lutowania, Wrocław 27-29.09.2004. Przegląd Spawalnictwa, 8-9/2004, p. 39-42. 